\title{
MATHEMATICAL MODELING OF ACTINIDIA ARGUTA (KIWIBERRY) DRYING KINETICS
}

\author{
Michał Bialik $^{\mathrm{a}}$, Ewa Gondek ${ }^{\mathrm{a} *}$, Artur Wiktor ${ }^{\mathrm{a}}$, Piotr Latocha ${ }^{\mathrm{b}}$, Dorota Witrowa-Rajchert ${ }^{\mathrm{a}}$ \\ ${ }^{a}$ Departmeny of Food Engineering and Process Management, Warsaw University of Life Sciences \\ ${ }^{\mathrm{b}}$ Department of Environmental Protection, Warsaw University of Life Sciences \\ "Corresponding author: e-mail: ewa_gondek@sggw.pl
}

\begin{tabular}{|c|c|}
\hline ARTICLE INFO & ABSTRACT \\
\hline $\begin{array}{l}\text { Article history: } \\
\text { Received: May } 2017 \\
\text { Received in the revised form: } \\
\text { June } 2017 \\
\text { Accepted: June } 2017\end{array}$ & $\begin{array}{l}\text { Consumers and scientists exhibit a growing interest in bioactive } \\
\text { ingredients of natural origin with strong pro-health effects. Such } \\
\text { properties have been found in fruits of of Actinidia argute, commonly } \\
\text { known as kiwiberry (mini kiwi or hardy kiwi). Appropriate methods } \\
\text { and parameters of the drying process enable obtaining }\end{array}$ \\
\hline $\begin{array}{l}\text { Key words: } \\
\text { mini kiwi, } \\
\text { Actinidia arguta, } \\
\text { drying, } \\
\text { mathematical modeling, } \\
\text { water diffusion coefficient }\end{array}$ & $\begin{array}{l}\text { a product with preserved high pro-health properties. The obejctive of } \\
\text { this paper was to study the influence of the selected drying methods } \\
\text { on the drying kinetics of actinidia. Commonly known mathematical } \\
\text { models were used to describe the process. The kinetics of convective, } \\
\text { microwave-convective, infrared and vacuum drying was investigated. } \\
\text { The process was performed until samples reached dimensionless } \\
\text { moisture ratio (MR) of } 0.02 \text {. The quickest method was vacuum drying } \\
\text { reaching moisture ratio target after } 286 \text { min, and the slowest was } \\
\text { convective drying characterized by } 1352 \text { min of drying. In general, } \\
\text { Midilli et al.'s model was evaluated as the most adequate for descrip- } \\
\text { tion of the moisture transfer in the fruit samples. }\end{array}$ \\
\hline
\end{tabular}

\section{Introduction}

Fresh fruits and vegetables cultivated with the use of traditional techniques are available only for a short time after harvesting, which results in their short-term access and deficiency during the remainder of the year. Drying is one of the most popular methods of increasing their durability. This method removes water from material, using phase transition, up to the point of water activity level which stops growth of the microflora and slows both chemical and enzymatic reactions (Vega-Gálvez et al., 2011; Maritza et al., 2012). Moreover, drying lowers the mass and volume of a dried product, which significantly decreases the packing, transportation and storage costs (Lewicki, 2006). Properly dried material can be kept for long time and it is easy for rehydration (Strumiłło, 2005; Janowicz and Lenart, 2007). From the industrial point of view, increasing food durability by drying should be cost and energy effective, and swift. The most popular but ineffective method of drying is convective drying. Such situation results mainly from high investment costs of the alternative drying techniques. Convective dried material is different from raw fruits by color, taste, smell and texture. Shrinkage of product often causes it to be less attractive for direct con- 
sumption than its fresh equivalent (Ciurzyńska et al., 2012). Using an adequate method and specific parameters increases effectiveness of the process and gives a product desired sensorial and chemical properties. However, the drying procedure should be selected individually for each product depending on the desired properties of the final product (Lewicki, 2006).

Kiwiberry (Actinidia arguta), also known as hardy kiwifruit or mini kiwi isis a popular plant which originates from south-eastern China and in the 19th century it was introduced to the different parts of the world. Hardy kiwifruits are small, sweet-sour gelatinous berries with a number of small seeds, and because they have smooth skin they can be eaten as a whole. In comparison to Actinidia chinensis and Actinidia deliciosa (popular kiwifruits), they are ten-fold smaller, and they mass is between few to a dozen grams (Latocha, 2013). Actinidia plant can reach up to $30 \mathrm{~m}$ of height and crop 30 to $50 \mathrm{~kg}$ of fruits. The harvest is performed in the second half of September, and fully grown fruits can fall from or stay on the trees (Sękowski, 1993). Harvested fruits can be stored in cold chambers up to 6 weeks, and after reaching consumption maturity up to one week.

Actinidia arguta's fruits have proven antioxidant and bacteriostatic properties, and they are widely known for their strong enzymatic activity (Basile et al., 1999; Rush et al., 2002; Duttaroy and Jørgensen, 2004). They are used in traditional Russian medicine against gastrointestinal parasites, digestion and intestinal passage. Researchers suggest that in places with traditional actinidia plantations their usage in traditional medicine remedies is reported. Kiwiberry are rich in vitamin C, minerals, phenolic acids and pigments (Latocha et. al., 2010). These properties decay during storage and thus these fruits need special treatment for their preservation. Different methods of prolonging availability of actinidia were tested and two of them were proven to be possible and efficient - drying and freezing (Latocha, 2013).

The efficiency and duration of the drying process requires optimization of its methods and parameters. From the engineering point of view, the control of variables demands evaluation of concatenated non-linear mass and heat properties. In this context, mathematical modeling of the drying process is an important field of study. Process modeling allows food engineers to choose the most suitable method and conditions of the process in order to meet the needs and to forecast progress and course of the process. Optimization of these procedures allows control of the process which than allows drying heat-sensitive foods and bio products (Vega-Gálvez et. al., 2010).

\section{Plant material}

The study was carried out using fruits of hardy kiwi (Actinidia arguta 'Bingo'), strain registered at the Polish Official Variety Testing (COBORU) in 2010. 'Bingo' fruits are rich in vitamin C, have pleasant sensory characteristics and good consumer acceptance (Latocha, 2012). Plants grew in the commercial plantation under supervision of scientists from the Environmental Protection Department, Warsaw University of Life Sciences (SGGW), Poland. Fruits were collected at the eating maturity stage (soft) with solid substance at $0.215 \mathrm{~g} \cdot \mathrm{g}^{-1}$. Until needed, fruits were stored in a dark chamber at $4^{\circ} \mathrm{C}$. Before each experiment, fruits were withdrawn from the storage compartment, left to achieve room temperature $\left(22^{\circ} \mathrm{C}\right)$, washed with tap water and cut into halves. 
Mathematical modeling...

\section{Drying}

All drying procedures were performed in convective (CD), infrared-convective (IR-C), microwave-convective (M-C), vacuum (V-D) or sublimation (SD) laboratory dryers. Halves of the fruits were placed on perforated trays (or non-perforated trays in the case of SD) with $3.95 \mathrm{~kg} \cdot \mathrm{m}^{-2}$ of samples facing upwards. In the case of CD and IR-D air flown parallel whereas in the case of M-C, airflow was perpendicular to the perforated tray. Drying was performed until a dimensionless moisture ratio of 0.02 was attained. The mass of the material was recorded continuously (every 2 minutes) during drying with the accuracy of $0.1 \mathrm{~g}$. Dry matter content in raw and dried kiwiberry was measured according to the Polish Standard PN-90/A-75101/03. Each drying run was performed twice. For the convective (CD), infrared-convective (IR-C) and microwave-convective (M-C) drying the air velocity was $2 \mathrm{~m} \cdot \mathrm{s}^{-1}$. For vacuum and convective drying temperature was $70^{\circ} \mathrm{C}$, and for microwave-convective and infrared-convective drying air was set at the room temperature $\left(22^{\circ} \mathrm{C}\right)$. Microwave-convective process was performed at power of microwaves of $250 \mathrm{~W}$ $\left(1.45 \mathrm{~W} \cdot \mathrm{g}^{-1}\right)$. Vacuum drying was performed under pressure of $4 \mathrm{kPa}$. Infrared radiation had intensity of $7,875 \mathrm{~kW} \cdot \mathrm{m}^{-2}$, the light source was positioned $20 \mathrm{~cm}$ above the dried layer.

\section{Mathematical modeling}

Modeling of the drying kinetics allows comparison of drying methods and it is important for a thorough study of the process. In this article, commonly used mathematical models, listed in Table 1, were used to evaluate the drying kinetics of kiwiberry fruits. Drying curves were plotted as a function of dimensionless moisture ratio (MR) during drying. The moisture ratio was calculated as follows (Wiktor et al., 2013):

$$
M R=\frac{u_{\tau}-u_{e}}{u_{0}-u_{e}}
$$

where:

$\mathrm{u}_{\mathrm{e}} \quad$ - the equilibrium moisture content, $\left(\mathrm{g} \mathrm{H}_{2} \mathrm{O} \cdot \mathrm{g}^{-1} \mathrm{dm}\right)$

$\mathrm{u}_{0} \quad$ - the initial moisture content, $\left(\mathrm{g} \mathrm{H}_{2} \mathrm{O} \cdot \mathrm{g}^{-1} \mathrm{dm}\right)$

$\mathrm{u}_{\tau} \quad$ - the moisture content at each moment of the process, $\left(\mathrm{g} \mathrm{H}_{2} \mathrm{O} \cdot \mathrm{g}^{-1} \mathrm{dm}\right)$

Regression analysis was performed using Table Curve 2D v5.01 software (SYSTAT Software, Inc., Chicago, IL, USA). In order to select the model that best describes the data, the coefficient of determination $\left(\mathrm{R}^{2}\right)$, reduced chi-squared statistic $\left(\chi^{2}\right)$, and root mean square error (RMSE) were used. The $\chi^{2}$ and RMSE were calculated as follows:

$$
\begin{gathered}
R M S E=\sqrt{\frac{\sum_{i=1}^{N}\left(M R_{i, p}-M R_{i, e}\right)^{2}}{N}} \\
\chi^{2}=\frac{\sum_{i=1}^{N}\left(M R_{i, p}-M R_{i, e}\right)^{2}}{N-n}
\end{gathered}
$$


where:

$\mathrm{MRi}, \mathrm{p}$ - the predicted dimensionless moisture ratio

$\mathrm{MRi}$, e - the experimental dimensionless moisture ratio

$\mathrm{N} \quad-$ is the number of observations, and $\mathrm{n}$ is the number of constants in the model equation

High $\mathrm{R}^{2}$ values (nearing 1), and lower both $\chi^{2}$ and RMSE indicate that the model better fits experimental data. The effective water diffusion coefficient was computed using Table Curve 2D v5.01 software from the simplified equation for Fick's second law of diffusion (Table 1) for an infinite slab - approximation of this type is allowed for long drying times (Crank, 1975).

Table 1.

Choice-set of the selected mathematical models used in the experiment

\begin{tabular}{|c|c|c|c|}
\hline Model № & Model name & Model equation & Reference \\
\hline 1 & Newton & $M R=\exp (-k \cdot \tau)$ & (Demir et al., 2004) \\
\hline 2 & Page & $M R=\exp \left(-k \cdot \tau^{a}\right)$ & (Sarimeseli 2011) \\
\hline 3 & $\begin{array}{l}\text { Henderson and } \\
\text { Pabis }\end{array}$ & $M R=\mathrm{a} \cdot \exp (-k \cdot \tau)$ & (Rahman et al., 1997) \\
\hline 4 & Logarithmic & $M R=a \cdot \exp (-k \cdot \tau)+b$ & (Sarimeseli 2011) \\
\hline 5 & Midilli et al. & $M R=\mathrm{a} \cdot \exp \left(-k \cdot \tau^{c}\right)+b \cdot \tau$ & (Midilli et al., 2002) \\
\hline 6 & Wang and Singh & $M R=1+\mathrm{a} \cdot \tau+b \cdot \tau^{2}$ & (Wang and Singh 1978) \\
\hline 7 & Logistic & $M R=\frac{b}{(1+\mathrm{a} \cdot \exp (k \cdot \tau))}$ & (Soysal et al., 2006) \\
\hline 8 & Two-factor & $\begin{aligned} M R=a \cdot \exp (-k \cdot \tau) & \\
& +b \cdot \exp \left(-k_{i} \cdot \tau\right)\end{aligned}$ & (Arslan et al., 2010) \\
\hline 9 & $\begin{array}{l}\text { Simplified Fick's } \\
\text { second law of } \\
\text { diffusion }\end{array}$ & $M R=\frac{8}{\pi^{2}} \cdot\left(-\frac{\pi \cdot D_{e f f} \cdot \tau}{4 \cdot L^{2}}\right)$ & $\begin{array}{c}\text { (Ramaswamy and Nsozi } \\
\text { 1998) }\end{array}$ \\
\hline
\end{tabular}

$k, k_{i}$ drying rates $\left(\min ^{-1}\right) ; a, b, n$ - model parameters, $\tau$ - time (s); $D_{\text {eff }}$ - effective water diffusion coefficient $\left(\mathrm{m}^{2} \cdot \mathrm{s}^{-1}\right) ; L-$ half of the material thickness $(\mathrm{m})$.

\section{Results and discussion}

Drying curves of kiwi samples are presented in fig. 1. The utilized method of drying impacted on the drying curves. The lowest dimensionless moisture ratio after $60 \mathrm{~min}$ of drying was established for the $\mathrm{M}-\mathrm{C}$ sample $(\mathrm{MR}=0.52)$. In the case of $\mathrm{C}-\mathrm{D}, \mathrm{IR}-\mathrm{C}, \mathrm{V}-\mathrm{D}$ protocols values of MR were equal to $0.73,0.71,0.73$, respectively. After $180 \mathrm{~min}$ of drying the lowest and equal moisture ratio was registered for $\mathrm{M}-\mathrm{C}$ and $\mathrm{V}-\mathrm{D}$ dried fruits with MR reaching 0.26.

Vacuum dried actinidia reached moisture value 0.02 after 286 min of drying, and at that moment values for C-D and IR-C were between 0.25-0.26 and for M-C 0.14. Desired MR values for C-D, IR-C and M-C were reached after 1352, 1152, and 544 min respectively. 
Mathematical modeling...

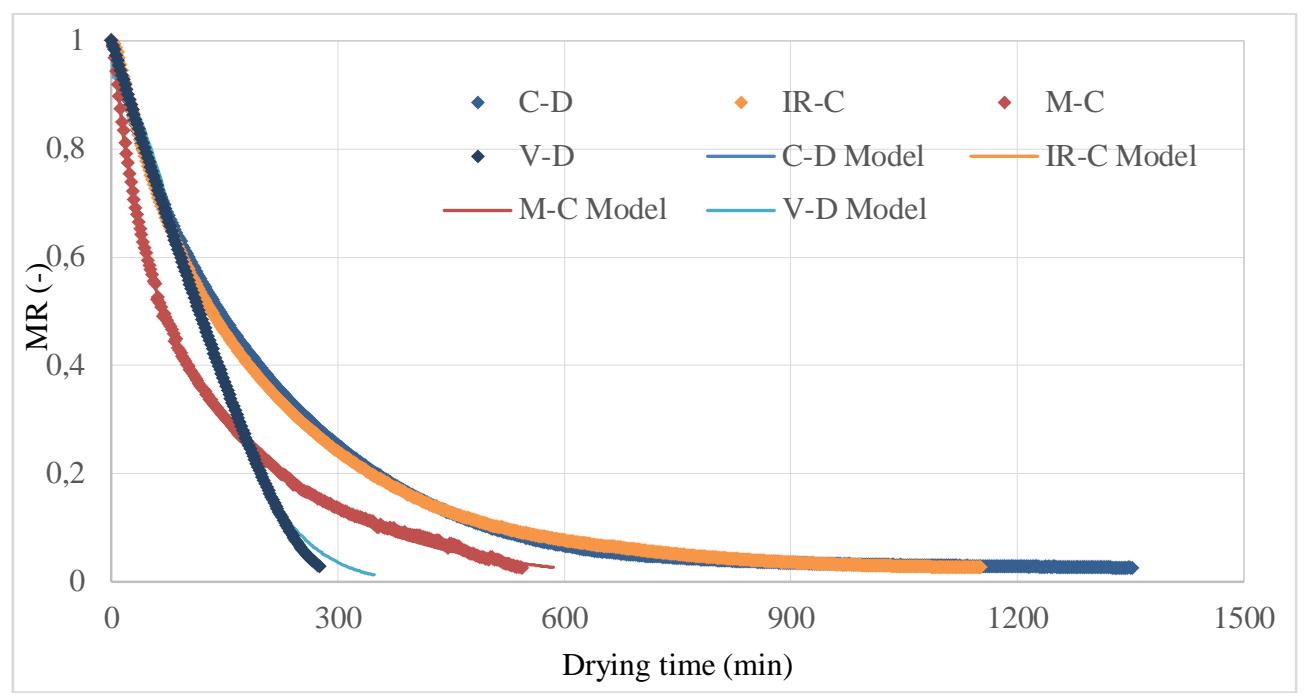

Figure 1. Experimental and forecasted (based on best fitting model) drying curves of kiwi fruits

Chin et al., (2015) studied drying kinetics of kiwifruit (Actinidia deliciosa) using convective drying at different temperatures of the process. They discovered that total drying time, required for reaching equilibrium moisture content of kiwi slices $0.3 \mathrm{~cm}$ thick at $50^{\circ} \mathrm{C}$ and $60^{\circ} \mathrm{C}$, was 1500 and 1200 minutes. They have proven that along with the increase of drying temperature the drying rate will grow which was dominant by internal moisture diffusion. Higher drying temperature stimulates the diffusion of moisture to the surface which results in a higher rate of heat transfer and faster evaporation.

The obtained results show that the vacuum drying procedure, which is 4 times faster than using most popular convective drying, is the best methods for quick drying. Microwave drying proved to be less effective than expected because of the limited microwave power that could be used without local burning of the material. Therefore, such parameters of M-C drying were selected to prevent overheating of the material and its local overburning. Thus, air temperature was set to be equal to ambient temperature $22^{\circ} \mathrm{C}$ at $2 \mathrm{~m} \cdot \mathrm{s}^{-1}$, to dispose removed moisture and provide a cooling effect. During microwave-convective drying two distinctive stages of drying were observed, which can be explained using mechanism of interaction of dielectric materials with microwave energy. The exposure of food to the microwaves causes bipolar rotation of the water dipole which results in heating by friction. This behavior is described by electrical permeability $\varepsilon^{*}$, in which the dielectric constant $\varepsilon^{\prime}$ is a crucial component. Moreover, it should be emphasized that the higher the moisture content of the material the greater the value of $\varepsilon^{\prime}$ (Wiktor et al., 2012b). In the beginning berries had high moisture content which allowed fast water removal according to the described mechanism. After reaching the critical value of $\mathrm{MR}=0.22$ the water content was too low to generate enough heat. As a result, the second phase of drying process was much slower with dynamics similar to the convective drying. Commonly performed convective drying turned out to be time and thus energy consuming. It can be assumed that the 
structure, high water and sugar contents of the material slowed the process. Similar kinetics of drying was also observed for infrared drying.

Mathematical modeling is a key tool for scaling up the process from laboratory to the industrial capacities. The best fitting model can be used to predict time needed for reaching desired water content (Wiktor et al., 2013). Statistical analysis (Table 3) has shown that in the cases of C-D, M-C, and V-D samples the drying kinetics could be fitted by the model of Midilli et al., (2002). The coefficient of determination $\left(\mathrm{R}^{2}\right)$ was in the range between 0.999 to 0.997 , root mean square error (RMSE) from 0.00358 to 0.01477 and reduced mean chisquared statistic $\left(\chi^{2}\right)$ ranged from $1.756 \cdot 10^{-5}$ to $2.349 \cdot 10^{-3}$. For infrared drying the best fitting model was a two-factor model, with $\mathrm{R}^{2}$ at 0.998 , RMSE at 0.00981 and $\chi^{2}$ at $2.349 \cdot 10^{-3}$.

Analysis conducted by Chin et al., (2015) has shown that for convective drying of kiwi slices in different temperatures, among used models the best fitting was obtained using simplified Fick's second law of diffusion. The coefficient of determination $\left(\mathrm{R}^{2}\right)$ was in the range between 0.998 to 0.999 , RMSE from 0.0052 to 0.0255 and $\chi^{2}$ ranged from $9.275 \cdot 10^{-5}$ to $6.72 \cdot 10^{-4}$.

Differences between tested models were relatively small which means that process of drying of hardy kiwi using tested methods can be predicted and adjusted according to the needs and specifications. Comparison of the results found in the literature also shows that drying slices of kiwifruit and halves has strong resemblance in their kinetics (Chin et al., 2015).

Table 2.

Statistical analysis of evaluated best fitted mathematical models for tested methods of drying

\begin{tabular}{lcccc}
\hline Drying method & Model name & RMSE & $\chi^{2}$ & $\mathrm{R}^{2}$ \\
\hline C-D & Midilli et al. & 0.00419 & $1.756 \cdot 10^{-5}$ & 0.999 \\
M-C & Midilli et al. & 0.00358 & $1.167 \cdot 10^{-3}$ & 0.999 \\
IR-C & Two-factor & 0.00981 & $2.349 \cdot 10^{-3}$ & 0.998 \\
V-D & Midilli et al. & 0.01477 & $2.181 \cdot 10^{-3}$ & 0.997 \\
\hline
\end{tabular}

The water diffusion coefficient was influenced by the drying method. Usually its values range between $10 \cdot 10^{-11}$ to $10 \cdot 10^{-9} \mathrm{~m}^{2} \cdot \mathrm{s}^{-1}$ (Aghbashlo et al., 2008). The highest values were obtained for kiwiberries processed with microwave-convection and vacuum drying methods. This methods provided the effective water coefficient values between $1.151 \cdot 10^{-9}$ and $1.441 \cdot 10^{-9} \mathrm{~m}^{2} \mathrm{~s}^{-1}$. Over ten times lower results were measured for convective and infrared drying $-D_{\text {eff }}$ in these cases ranged between $7.503 \cdot 10^{-10}$ and $7.829 \cdot 10^{-10} \mathrm{~m}^{2} \cdot \mathrm{s}^{-1}$ respectively. Such differences caused by drying methods and conditions correlate with values described by other authors. Thuwapanichayanan et al., (2011) studied effect of drying temperature on banana slices showing that $D_{\text {eff }}$ can take values from $0.9 \cdot 10^{-10} \mathrm{~m}^{2} \cdot \mathrm{s}^{-1}$ for drying temperature of $70^{\circ} \mathrm{C}$ to $10 \cdot 10^{-10} \mathrm{~m}^{2} \cdot \mathrm{s}^{-1}$ for $100^{\circ} \mathrm{C}$. Wiktor et al., (2012a) analyzed effects of different parameters of microwave-convective drying of basil leaves and they discovered that changing microwaves power from 200 to $300 \mathrm{~W}$ increased $\mathrm{D}_{\text {eff }}$ by $35-85 \%$, but temperature of the process had smaller effect and influenced measured values by $22-67 \%$. 
Mathematical modeling...

Table 3.

Effective water diffusion coefficient computed from simplified Fick's second law of diffusion

\begin{tabular}{lc}
\hline Drying method & $D_{\text {eff }}\left(\mathrm{m}^{2} \cdot \mathrm{s}^{-1}\right)$ \\
\hline C-D & $7.503 \cdot 10^{-10} \pm 3.24 \cdot 10^{-12}$ \\
M-C & $1.151 \cdot 10^{-9} \pm 1.23 \cdot 10^{-11}$ \\
IR-C & $7.829 \cdot 10^{-10} \pm 3.50 \cdot 10^{-12}$ \\
V-D & $1.441 \cdot 10^{-9} \pm 2.20 \cdot 10^{-11}$ \\
\hline
\end{tabular}

\section{Conclusions}

The results indicate that the method of drying influences the drying process of kiwiberry. Utilization of the vacuum drying technique allowed reduction of the drying time by $80 \%$ in comparison to convective drying. The lower drying time can result in a reduction of energy consumption and preservation of pro-health properties. The effective water diffusion coefficient was higher for the samples obtained using microwave-convection and vacuum than using convective or infrared drying. Investigation proved that in most cases Midilli et al.'s (2002) model was the most adequate to describe the drying kinetics of hard kiwi tissue. The obtained data can be helpful for industrial-scale process design.

\section{Bibliography}

Aghbashlo, M., Kianmehr, M.H., Samimi-Akhijahani, H. (2008). Influence of drying conditions on the effective moisture diffusivity, energy of activation and energy consumption during the thin-layer drying of beriberi fruit (Beriberidaceae). Energy Conversion and Management 49, 2865-2871.

Arslan, D., Özcan, M.M., Okyay Mengeş, H. (2010). Evaluation of drying methods with respect to drying parameters, some nutritional and colour characteristics of peppermint (Menthapiperita L.). Energy Conversion and Management, 51, 2769-2775.

Basile, A., Giorgano, S., Lopez-Saez, J.A., Cobianchi, C. (1999). Antibacterial activity of pure flavonoids isolated from mosses. Phytochemistry, 52, 1479-1482.

Chin, S.K., Siew, E.S., Soon, W.L. (2015). Drying characteristics and quality evaluation of kiwi slices under hot air natural convective drying method. International Food Research Journal, 22(6), 2188-2195.

Ciurzyńska, A., Piotrowski, D., Lenart, A., Łukasik, P. (2012). Sorption Properties of Vacuum-Dried Strawberries. Drying Technology, 30, 850-858.

Crank, J. (1975). The mathemacics of diffusion. Drying Technology, 30, 347.

Demir, V., Gunhan, T., Yagcioglu, A.K., Degirmencioglu, A. (2004). Mathematical modeling and the determination of some quality parametersof air-dried bay leaves. Biosystems Engineering, 88(3), 325-335.

Duttaroy, A.K., Jørgensen, A. (2004). Effects of kiwifruit consumption on platelet aggregation and plasma lipids in healthy human volunteers. Platelets, 15(5), 287-292.

Janowicz, M., Lenart A. (2007). Rozwój i znaczenie operacji wstępnych w suszeniu żywności. Właściwości Fizyczne Suszonych Surowców i Produktów Spożywczych, Komitet Agrofizyki PAN, Wydawnictwo Naukowe FRNA, Lublin, 15-33. 
Lewicki, P.P. (2006). Design of hot air drying for better foods. Trends Food Science Technology, 17(4), 153-163.

Latocha, P. (2012). Some morphological and biological features of 'Bingo' - a new hardy kiwifruit cultivar from Warsaw University of Life Sciences (WULS) in Poland. Rocznik Polskiego Towarzystwa Dendrologicznego, 60, 61-67.

Latocha, P., Krupa, T., Wołosiak, R., Worobiej, E., Wilczak, J. (2010). Antioxidant activity and chemical difference in fruit of different Actinidia sp. International Journal of Food Sciences and Nutrition, 61(4), 381-394.

Latocha, P., Wołosiak, R., Worobiej, E., Krupa, T. (2013). Clonal differences in antioxidant activity and bioactive constituents of hardy kiwifruit (Actinidia arguta) and its year-to-year variability. Journal of the Science of Food and Agriculture, 93, 1412-1419.

Maritza, A.M., Sabah, M., Anaberta, C.-M., Montejano-Gaitán, J. G., Allaf, K. (2012). Comparative study of various drying processes at physical and chemical properties of strawberries. Procedia Engineering, 42, 267-282.

Midilli, A., Kucuk, H., Yapar, Z. (2002). A new model for single layer drying. Drying Technology, 1503-1513.

Rahman, M.S., Perera, C.O., Thebaud, C. (1997). Desorption isotherm and heat pump drying kinetics of peas. Food Research International, 30, 485-491.

Ramaswamy, H.S., Nsonzi, F. (1998). Convective air drying kinetics of osmotic ally pre-treated blueberries. Drying Technology, 16, 743-759.

Rush, E.C., Patel, M., Plank, L.D., Ferguson LR. (2002). Kiwifruit promotes laxation in the elderly. Asia Pacific Journal Clinical Nutrition, 11(2), 164-168.

Sarimeseli, A. (2011). Microwave drying characteristics of coriander (Coriandrum sativum L.) leaves. Energy Conversion and Management, 52, 1449-1453.

Sękowski, B. (1993). Pomologia systematyczna. Wydawnictwo Naukowe PWN, Warszawa, 2, 172-175.

Soysal, Y., Öztekin, S., Eren, Ö. (2006). Microwave drying of parsley: Modeling, kinetics, and energy aspects. Biosystems Engineering, 93, 403-413.

Strumiłło, C. (2005). On perspective developments in drying. Materiały z Sympozjum "Proceedings of the $11^{\text {th }}$ Polish Drying Symposium XI PSS”, Poznan, Polska, 13-16 September 2005, materials provided on CD.

Thuwapanichayanan, R., Prachayawarakorn, S., Kunwisawa, J., Soponronnarit, S. (2011). Determination of effective moisture diffusivity and assessment of quality attributes of banana slices during drying. LWT - Food Science and Technology, 44(1), 1502-1510.

Vega-Gálvez, A., Miranda, M., Díaz, L. P., Lopez, L., Rodriguez, K., Di Scala, K. (2010). Effective moisture diffusivity determination and mathematical modelling of the drying curves of the olivewaste cake. Bioresource Technology, 101, 7265-727.

Vega-Gálvez, A., Miranda, M., Clavería, R., Quispe, I., Vergara, J., Uribe, E., Paez, H., Di Scala, K. (2011). Effect of air temperature on drying kinetics and quality characteristics of osmotreated jumbo squid (Dosidicus gigas). LWT, Food Science and Technology, 44(1), 16-23.

Wang, C.Y., Singh, R.P. (1978). Use of variable equilibrium moisture content in modeling rice drying. Transactions of the American Society of Agricultural Engineers, 11, 668-672.

Wiktor, A., Iwaniuk, M., Śledź, M., Nowacka, M., Chudoba, T., Witrowa-Rajchert, D. (2013). Drying Kinetics of Apple Tissue Treated by Pulsed Electric Field. Drying Technology, 31, 112-119.

Wiktor, A., Łuczywek, K., Witrowa-Rajchert, D. (2012a). Modelowanie matematyczne kinetyki suszenia mikrofalowo-konwekcyjnego liści bazylii. Zeszyty Problemowe Postępów Nauk Rolniczych, 570, 127-141.

Wiktor, A., Nowacka, M., Śledź, M., Selke, M., Witrowa-Rajchert, D. (2012b). Kinetyka suszenia konwekcyjnego wspomaganego ogrzewaniem mikrofalowym miąższu jabłka - dobór modelu matematycznego. Nauki Inżynierskie i Technologie, 4(7), 99-111. 
Mathematical modeling...

\section{MODELOWANIE KINETYKI PROCESU SUSZENIA OWOCÓW MINI KIWI (ACTINIDIA ARGUTA)}

Streszczenie. W ostatnich latach wzrasta zainteresowanie naukowców i konsumentów bioaktywnymi składnikami żywności o silnym działaniu prozdrowotnym. Takie właściwości stwierdzono w owocach aktinidii (Actinidia arguta), powszechnie znanej, jako mini kiwi. Wykazano, że suszenie jest dobra metoda utrwalania owoców i pozwala uzyskać produkt o zachowanych wysokich właściwościach prozdrowotnych, pod warunkiem doboru odpowiedniej dla surowca metody i parametrów procesu. Celem pracy było zbadanie wpływu wybranych metod suszenia na kinetykę suszenia owoców aktinidii. Do opisu procesu wykorzystano powszechnie znane modele, dostępne w literaturze matematyczne. Badano kinetykę suszenia: konwekcyjnego, mikrofalowo-konwekcyjnego, podczerwonego i próżniowego. Proces prowadzono do momentu uzyskania próbek o bezwzględnym współczynniku wilgotności (MR) wynoszącym 0,02 . Stwierdzono ze najszybszą metodą było suszenie próżniowe, które pozwoliło osiągnać docelowy współczynnik MR po 286 minutach, a najwolniejszą było suszenie konwekcyjne, po 1352 min suszenia. Spośród analizowanych modeli matematycznych, najbardziej odpowiedni do opisu kinetyki suszenia mini kiwi był model Midilliego.

Słowa kluczowe: mini kiwi, Actinidia arguta, suszenie, modelowanie matematyczne, współczynnik dyfuzji wody 